\title{
MEMBANGUN LEGAL BASIS PENGISIAN JABATAN DALAM PENINGKATAN KUALITAS PELAYANAN PUBLIK
}

\author{
Retno Mawarini Sukmariningsih \\ Fakultas Hukum Universitas 17 Agustus 1945 Semarang \\ Jl. Pawiyatan Luhur Bendan Dhuwur Semarang \\ email : mawarini_sukma@yahoo.co.id
}

\begin{abstract}
Civil servants management at the Regional Agencies implemented by local governments in accordance with the legislation., The substance of the requirements for filling the positions (Contract Position Determination and Structural), can be set at the level of local regulations. A Civil State Apparatus in addition to unifying the nation primarily as a public servant and qualified professionals. In building the legal basis of structural filling positions, especially at the local level through the establishment of regional regulation is not easy, a fact often creates debate table because political aspects are the dominant rather than normative aspects required in forming the Government Area and the persistence of attitudes like and dislike.
\end{abstract}

Keywords : Legal Basis, Filling Positions, Quality Of Public Services

\begin{abstract}
Abstrak
Manajemen PNS pada Instansi Daerah dilaksanakan oleh pemerintah daerah sesuai dengan peraturan perundang-undangan., maka materi muatan mengenai persyaratan pengisian jabatan (Penetapan dan Kontrak Jabatan Struktural), dapat diatur pada peraturan perundangan tingkat daerah. Seorang Aparatur Sipil Negara disamping sebagai pemersatu bangsa utamanya adalah sebagai pelayan publik yang professional dan berkualitas. Dalam membangun legal basis pengisian jabatan struktural khususnya di lingkungan pemerintah daerah melalui pembentukan PERDA tidaklah gampang, fakta seringkali menimbulkan debat table karena aspek politisnya menjadi mendominasi ketimbang aspek normative diharuskan dalam membentuk PERDA dan masih adanya sikap like and dislike.
\end{abstract}

Kata kunci : Legal Basis, Pengisian Jabatan, Kualitas Pelayanan Publik

\section{A. Pendahuluan}

Sistem Pemerintahan Birokrasi Negara merupakan suatu instrument yang sangat efektifuntuk pengendalian kekuasaan.Hal ini amat lah mudah untuk di duga bahwa dengan birokrasi publik yang juga menjadi bagian dari Birokrasi Negara menjadi efektif bagi penguasa untuk mempertahankan kekuasaannya hal ini menyebabkan adanya krisis kepercayaan terhadap sistem pemerintahan birokrasi Negara kita yang pada saat ini sangatlah tinggi.
Birokrasi publik telah menempatkan dirinya lebih sebagai alat penguasa ketimbang pelayan masyarakat. Kepentingan penguasa cenderung mendominasi dalam kehidupan dan perilaku birokrasi publik. Hal ini tercermin dalam proses kebijakan publik dimana kepentingan masyarakat seringkali termarginalkan manakala keduanya yaitu kepentingan penguasa dan kepentingan masyarakat tidak berjalan bersama. Ruang masyarakat yang dimiliki semakin terbatas sehingga tingkat partisipasi dalam mengawal proses kebijakan public juga 
semakin tidak maksimal. Akibatnya banyak kebijakan publik dan program-program pemerintah yang tidak responsif dan tidak bisa maksimal dalam implementasinya.

Secara empirik persoalan rekrutmen jabatan struktural, meliputi: (1.)komitmen menjalankan tugas secara professional, yakni komitmen untuk pencapaian visi dan misi dan kinerja yang baik; (2). Kemampuan menjalankan tugas sesuai peraturan perundangan Tugas Pokok dan Fungsi (TUPOKSI) dengan bersandarkan pada asas-asas pemerintahan yang baik; (3). Kemampuan berinisiatip dan bertindak cepat dan tepat dalam mengatasi persoalan (kompetensi). Untuk itulah perlu ada legal basis rekrutmen pejabat structural yang menghasilkan kualitas, utamanya yang mampu memberikan kontribusi bagi peningkatan kualitas pelayanan publik ditingkat daerah .

Philipe Nonet \& Philip Selznick bahwa

Sarana hukum responsip, ${ }^{1}$ bisa menjadi jalan keluar terbaik bagi pengisian jabatan di lingkungan Pemerintah Daerah, dengan membuat Peraturan Daerah (PERDA) yang dapat melengkapi peraturan perundangan dan tidak bertentangan dengan hukum positip atau peraturan perundangan yang berlaku. Paradigma baru dengan melakukan perubahan sikap birokrasi yang menganggap dirinya sebagai pelayan dari masyarakat sebagai pelanggan, kiranya dapat terwujud dengan melakukan perubahan pola rekrutmen pejabat struktural yang mampu mengatasi persoalan-persoalan selama ini. Perubahan ini dengan menggunakan instrument hukum dalam bentuk PERDA yang materi muatannya tidak mengandung aspek politis .

\section{B. Pembahasan}

Dalam membangun legal basis pengisian jabatan structural khususnya di lingkungan pemerintah daerah melalui pembentukan PERDA tidaklah gampang, karena dalam fakta seringkali menimbulkan debate table karena aspek politisnya
Retno Mawarini .S, Membangun Legal Basis Pengisian Jabatan menjadi mendominasi ketimbang aspek yang secara normative diharuskan dalam membentuk PERDA.Pemikiran konsep Negara hukum yang diawali oleh Plato dan Aristoteles barangkali dapat menjadi fondasi awal dalam membentuk Perda mengenai persyaratan pengisian jabatan di lingkungan Pemda untuk menghasilkan kualitas pelayanan publik yang diharapkan oleh masyarakat. Dalam sejarah perkembangan secara akademik dapat diklasifikasikan atas Negara hukum dan Negara hukum materil. Pengertian Negara hukum formil, yang muncul pada abad 19 ini dipandang sebagai pelajaran tentang kedaulatan dari parlemen.

Negara hukum dipahami sebagai suatu Negara yang seluruh aksinya didasarkan dan diatur oleh undang-undang, yang telah ditetapkan semula dengan bantuan dari badan pemberi suara rakyat. ${ }^{2}$ Pandangan yang demikian ini hanya menempatkan tugas Negara hukum sebagai penjaga keamaman dan ketertiban. Oleh karena itu juga disebut sebagai "Negara penjaga malam" (nachtwakerstaat). Dalam tugasnya yang terbatas ini, Negara tidak boleh memasuki pergaulan hidup individu mapun masyarakat.Kebebasan atau kemerdekaan warga Negara benar-benar tidak boleh diganggu oleh Negara. Maksudnya ada bagian-bagian dari kehidupan masyarakat atau individu yang tidak boleh menjadi obyek urusan Negara atau pemerintah. ${ }^{3} \mathrm{Hal}$ ini secara akademik sering disebut sebagai Negara hukum klasik. Seperti yang dikemukakan oleh Frederick Yulius Stahl, Negara hukum yang memiliki ciri-ciri untuk melindungi hak asasi manusia sebagai berikut : Pemisahan atau pembagian kekuasaan untuk menjamin hak-hak asasi manusia, Pemerintah berdasarkan peraturan-peraturan; dan Peradilan administrasi Negara dalam perselisihan.

Dari ciri-ciri negara hukum, semua tugas Negara harus dapat dikembalikan pada jaminan perlindungan hak asasi manusia. Untuk itu pula hukum diartikan secara sempit, yakni pada peraturan-peraturan. Diluar itu tidak dapat menjadi

\footnotetext{
${ }^{1}$ Philipe Nonet \& Philip Selznick, 2007,Hukum Responsip, diterjemahkan dari Law and Society in Transition: Toward Responsive Law, Harper and Law, dinyatakan bahwa hukum diperankan sebagai instrument yang lebih dinamis bagi penataan social dan perubahan social, hlm. 84 .

${ }^{2}$ Philipus M Hadjon, 1987, Perlindungan Hukum Bagi Rakyat di Indonesia, Surabaya, cetakan pertama, Bina Ilmu, hlm. 72.

${ }^{3}$ Bagir Manan, 1990, Hubungan Anatara Pemerintah Pusat dan Daerah Berdasarkan UUD 1945, Disertasi, UNPAD, hlm. $43-45$.
} 
dasar pemerintah. Adanya peradilan administrasi hanyalah dimaksud sebagai sarana untuk menegakkan hukum materil, dalam pengertian yang sudah menjadi dasar dalam materi muatan undangundang saja. Konsep Negara hukum klasik tidak memungkinkan terjadinya pelayanan publik, karena urusan yang diselenggarakan terbatas. Sedangkan konsep negara hukum materiil, kemunculannya sebagai akibat dari tidak puasnya atas konsep negara hukum yang kolot, kuno, dan tidak sesuai dengan perkembangan jaman. Oleh karena itu pula dikenal sebagai welfare state atau negara kesejahteraan ${ }^{4}$.

Selanjutnya dalam hukum adminstrasi negara idealnya berperan secara aktif diseluruh lini kehidupan masyarakatnya dan pada hakekatnya administrasi negara juga melekat fungsi servis publik (bestuurzorg). Tugas yang sangat berat ini, memberikan konsekwensi logis kepada administrasi negara diberi kemerdekaan untuk bergerak atau bertindak, walaupun belum ada peraturan perundangan yang mengatur. Hal ini penting, terutama dalam kepentingan yang sangat mendesak, masyarakat membutuhkan pelayananannya. Jangan sampai terjadi, servis publik menjadi berhenti hanya karena belum ada peraturan perundangannya. Tentunya dapat dipahami bahwa peraturan yang ada tidak akan dapat menjangkau seluruh persoalan dalam kehidupan masyarakat.

\section{Membangunan Legal Basis Pengisian Jabatan Dalam Peningkatan Kualitas Pelayanan Publik di Pemerintah Daerah}

Dasar konstruktif dalam membangun legal basis pengisian jabatan di lingkungan pemerintah daerah dapat diawali dari Pasal 18 UUD Negara RI Tahun 1945, yang dalam pokok-pokok pikiran sebagai berikut :

a. Daerah Indonesia dibagi atas daerahdaerah propinsi dan daerah propinsi itu dibagi atas kabupaten dan kota, yang tiap-tiap provinsi,kabupaten dan kota mempunyai pemerintahan daerah yang diatur dengan undang-undang; b. Pengaturan tersebut memandang dan mengingati dasar musyawarah dalam system pemerintahan Negara dan hakhak asal-usul dalam daerah-daerah yang bersifat istimewa.

Dari uraian tersebut tidak ada ketentuan yang mengatur tentang persyaratan jabatan (Penetapan dan Kontrak Jabatan structural), maka menjadi kewenangan undang-undang yang mengatur. Kemudian yang di perintahkan oleh Undang-Undang Nomor 28 Tahun 1999 tentang Penyelenggara Negara Yang Bersih dan Bebas Dari Korupsi, Kolusi dan Nepotisme, artinya bahwa penyelenggara Negara haruslah tunduk pada undang-undang tersebut, selanjutnya dalamUndangUndang Nomor 5 Tahun 2014 Tentang Aparatur Sipil Negara, Pasal 10 menyebutkan bahwa pegawai Aparatur Sipil Negara mempunyai fungsi : sebagai pelaksana kebijakan publik, pelayan publik dan perekat pemersatu bangsa, jelas dari uraian tersebut bahwa seorang Aparatur Sipil Negara disamping sebagai pemersatu bangsa utamanya adalah sebagai pelayan publik yang professional dan berkualitas artinya tidak hanya sekedar memberikan pelayanan tetapi lebih ditekankan pada profesionalisme dari seorang Aparatur Sipil Negara dalam menjalankan tugasnya seperti yang terdapat dalam Pasal 11 hurufb yang menyatakan dengan tegas bahwa Aparatur Sipil Negara mempunyai tugas untuk memberikan pelayanan terhadap publik secara professional dan berkualitas.

Dalam Pasal 13 Jabatan Aparatur Sipil Negara terdiri atas: a. Jabatan Administrasi; $b$. Jabatan Fungsional; dan c. Jabatan Pimpinan Tinggi. Dalam tulisan ini khususnya jabatan Administrasi yang mempunyai tanggung jawab memimpin pelaksanaan seluruh kegiatan pelayanan publik. Kemudian seorang Pegawai Negeri Sipil (PNS) yang dipromosikan didasarkan perbandingan objektif antara kompetensi, kualifikasi, dan persyaratan yang dibutuhkan oleh jabatan, penilaian atas prestasi kerja, kepemimpinan, kerja sama, kreativitas, dan

\footnotetext{
${ }^{4}$ Miriam Budiardjo, 1980, Masalah Kenegaraan, Jakarta, Gramedia, hlm. 74.
} 
pertimbangan dari tim penilai kinerja PNS pada Instansi Pemerintah, tanpa membedakan jender, suku, agama, ras, dan golongan sedangkan PNS adalah warga Negara Indonesia yang memenuhi syarat tertentu yang diangkat sebagai Aparatur Sipil Negara secara tetap oleh Pejabat Pembina Kepegawaian untuk menduduki jabatan pemerintahan. Dalam Pasal 72 ayat (2) bahwa setiap PNS yang memenuhi syarat mempunyai hak yang sama untuk dipromosikan ke jenjang jabatan yang lebih tinggi.

Selanjutnya dalam Pasal 55 ayat (1) dari Undang-Undang No 5 Tahun 2014 mengatur juga tentang Manajemen PNS yang meliputi: a. penyusunan dan penetapan kebutuhan; $b$. pengadaan; c. pangkat dan jabatan; d. pengembangan karier; e. pola karier; f. promosi; $g$. mutasi; h. penilaian kinerja; i. penggajian dan tunjangan; j. penghargaan; $k$. disiplin; 1 . pemberhentian; m.jaminan pensiun dan jaminan hari tua; dan n. perlindungan. Ayat (2) Manajemen PNS pada Instansi Pusat dilaksanakan oleh pemerintah pusat sesuai dengan ketentuan peraturan perundangundangan. (3) Manajemen PNS pada Instansi Daerah dilaksanakan oleh pemerintah daerah sesuai dengan ketentuan peraturan perundang-undangan. Sampai dengan sekarang belum ada peraturan pelaksananya yang mendukung ketentuan dimaksud dan peraturan peundang-undangan yang berwenang mengaturnya secara eksplisit juga jtidak disebutkan oleh undang-undang Dari uraian diatas memberikan peluang bagi daerah untuk mengatur pengisian jabatan dengan PERDA sebagai peraturan pelaksanaannya.

Dengan memperhatikan Manajemen PNS yang meliputi: a. penyusunan dan penetapan kebutuhan; b. pengadaan; c. pangkat dan jabatan; d. pengembangan karier; e. pola karier; f. promosi; g. mutasi; h. penilaian kinerja dan Manajemen PNS pada Instansi Daerah dilaksanakan oleh pemerintah daerah sesuai dengan ketentuan peraturan
Retno Mawarini .S, Membangun Legal Basis Pengisian Jabatan perundang-undangan., maka materi muatan mengenai persyaratan pengisian jabatan (Penetapan dan Kontrak Jabatan Struktural), dapat diatur pada peraturan perundangan tingkat daerah. Pengertiannya adalah peraturan perundangundangan yang dibentuk oleh Pemerintah daerah atau salah satu unsur Pemerintah Daerah yang berwenang membuat peraturan perundang-undangan daerah. ${ }^{5}$ Apabila ternyata kehendak mengatur dalam peraturan daerah dapat terlaksana, maka peraturan daerah tersebut merupakan "perda responsif", karena tidak saja mengisi kekosongan hukum melainkan juga memenuhi tuntutan masyarakat yang menghendaki jabatan structural diemban oleh orangorang professional. Materi muatan Peraturan Daerah terhadap komitmen dalam menjalankan tugas jabatan, serta obyektifitas penilaian kinerja bagi pejabat structural merupakan hal yang tidak boleh diabaikan seperti yang dikemukakan oleh Retno MS: The substance of regional regulations reflects either appreciation or respect for the accomplishments,commitments and capabilities for civil servants carrying out the office duty.it realize the objectivity of the official assessment to structural performance, and it could also be a reference in developing career planning and development of regional civil servant to eliminate the attitude of like and dislike. ${ }^{6}$

Dalam Dinamikanya memang pelaksanaan manajemen aparatur sipil negara belum berdasarkan pada perbandingan antara kompetensi dan kualifikasi yang diperlukan oleh jabatan dengan kompetensi dan kualifikasi yang dimiliki calon dalam rekrutmen, sehingga pengangkatan, penempatan, dan promosi pada jabatan belum secara maksimal kalau di lihat dari tata kelola pemerintahan yang baik . Dengan demikian memberikan pemahaman tentang arti pentingnya legal basis, kedudukan dan status hukum dari peraturan daerah yang hendak dibentuk juga tidaklah mudah.

\footnotetext{
${ }^{5}$ Hans Kelsen, Dalam General Theory of Law, Russel \& Russel, New York, dinyatakan "peraturan perundang-undangan tingkat daerah dapat juga termasuk peraturan perundang-undangan yang dibentuk oleh Pemerintah Pusat yang berlaku untuk daerah atau wilayah tertentu", hlm. 304.

${ }^{6}$ Retno Mawarini Sukmariningsih,2014, "The right Man On The Right Job : Does the Local Regulation Support It ? The Empirical Evidence From Central Java, Indonesia”, Hyderabad, India, International Journal of Managerial Studies and Research Volume 2 ,Issue 3, Academicians Research Center, page 55
} 


\section{Peningkatan Kualitas Pelayanan Publik}

Dalam Undang-Undang Nomor 25 Tahun 2009 Tentang Pelayanan Publik memberikan batasan mengenai standart pelayanan yang meliputi : dasar hukum, persyaratan, system, mekanisme, prosedur, jangka waktu penyelesaian, biaya, produk pelayanan, sarana, prasarana, fasilitas, kompetensi pelaksana, pengawasan internal, penanganan pengaduan, saran dan jumlah pelaksana. Dari standart pelayanan yang sudah diatur, paling tidak dapat dimulai dari pengisian jabatan dan institusi penyelenggara Negara diisi secara profesional dan di dasarkan pada legal basis di tingkat daerah yang sesuai dengan karakter daerah masing-masing. Menurut Retno MS agar Pemerintah tidak menjadi bad government haruslah berfikir responsive karena ciri bad government antara lain adalah pemerintah lamban, arogan, bahkan bekerja ala kadarnya dan tidak mau menerima perubahan, kalau perubahan menuju kearah yang lebih baik kenapa tidak dilakukan?.' Pelayanan publik merupakan kegiatan atau rangkaian kegiatan dalam rangka pemenuhan kebutuhan pelayanan sesuai dengan peraturan perundang-undangan bagi setiap warga negara dan penduduk atas barang, jasa, dan/atau pelayanan administratif yang disediakan oleh penyelenggara pelayanan publik. (Pasal 1 Ayat 1 UU No.25 Tahun 2009).

Rekrutmen jabatan struktural merupakan suatu kebutuhan yang tidak dapat ditunda lagi, terutama dalam rangka peningkatan pelayanan publik, dan merupakan tindakan pencegahan terjadinya korupsi. Dari pandangan Negara hukum dalam pengertian materiil, administrasi negara berpeluang besar untuk dapat menggunakan "freiss ermessen." Meskipun demikian, tidak berarti pembentuk peraturan perundang-undangan membiarkan atau lebih banyak memberikan kesempatan kepada administrasi Negara untuk menjalankan kewenangan diskresinya. Untuk itu badan pembentuk peraturan perundangan harus senantiasa produktif memenuhi kebutuhan dalam memberikan fasilitasiuntuk pencapaian pelayananan publik secara maksimal.

Selanjutnya diskresi, merupakan salah satu kewenangan yang diatur dalam administrasi Negara, hal ini dapat menimbulkan besarnya resiko penyalahgunaan wewenang. Belum adanya legal basis sebagai pedoman, syarat ataupun mekanisme yang mengatur penetapan jabatan,tidak dapat dibiarkan begitu saja, agar diatur oleh administrasi Negara, karena hal ini akan beresiko tidak sesuai dengan aspirasi yang berkembang di masyarakat. Apalagi jika pejabat yang menetapkan pengangkatan jabatan struktural, juga merangkap yang menetapkan peraturan yang memuat pedoman, syarat dan mekanismenya, maka tidak ada lagi yang dapat melakukan pengawasan secara effektif dalam penerapan peraturan itu, atau justru akan membuat peraturan yang memberikan keleluasaan dirinya dalam menetapkan jabatan struktural. Jika demikian halnya, dapat beresiko menghambat pelaksanaan tugas-tugas jabatan, yang pada hakekatnya juga akan mengurangi kualitas dalam memberikan pelayanan publik. Untuk itu harus dihindari kewenangan mengatur pedoman, syarat dan mekanismenya diberikan kepada jabatan yang berwenang menetapkan jabatan struktural .

Seringkali pengisian jabatan dalam fakta belum menunjukkan kualifikasi, seperti yang terjadi seorang Kabag Hukum di jabat oleh seorang ahli ekonomi kemudian seorang sekretaris Dewan Perwakilan Rakyat Daerah di isi oleh seorang dokter hewan, hal ini akan mengakibatkan kualitas pelayanan publik tidak dapat berjalan maksimal. Selanjutnya terhadap Prinsip-prinsip umum pada awal kelahirannya untuk menciptakan pemerintahan yang baik adalah dimaksudkan untuk mencari solusi dalam pengawasan dari aspek legal tetapi dalam perkembangannya prinsip-prinsip umum ini menjadi nilai-nilai etik yang berkembang dalam hukum administrasi Negara.

${ }^{7}$ Retno Mawarini Sukmariningsih, Partisipasi StakeHolder Pelayanan Publik Dalam Mewujudkan Good Governance Dan Clean Government, Makalah disampaikan dalam seminar DPRD Prov.Jateng di Balai Agung, Tuntang, Kab. Semarang pada tgl. 9 Juni 2015 
Prinsip-prinsip umum seperti: azas Kebijaksanaan merupakan azas yang harus dimiliki dalam menjalankan tugasnya memberikan pelayanan umum, tidak perlu menunggu. Kebijaksanaan senantiasa harus melekat pada pola pikir, sehingga dalam melakukan tugasnya tidak saja mendasarkan pada peraturan perundangan yang ada, melainkan juga dapat melakukan tindakan kebijaksanaan selain yang diatur dalam peraturan perundangan guna penyelenggaraan kepentingan umum. Oleh Notohamidjojo, implikasinya ada tiga unsur, yaitui: ${ }^{8}$ pengetahuan yang tandas dan analisa situasi yang dihadapi; rancangan penyelesaian atas dasar "staat idée" maupun "rechtsidee"dan mewujudkan rancangan penyelesaian untuk mengatasi situasi dengan tindakan perbuatan dan penjelasan yang tepat, yang dituntut oleh situasi yang dihadapi.

Mengingat peranannya dalam penegakan hukum administrasi Negara yang sudah teruji, maka prinsip-prinsip umum dalam pemerintahan yang baik harus menjadi syarat kompetensi jabatan struktural Dengan kemampuan penguasaan azas-azas tersebut, maka diharapkan pejabat dapat memberikan pelayanan kepada masyarakat secara berkualitas. Ada Putusan Mahkamah Agung yang paling tidak dapat menjadi yurisprudensi bagi pengisian jabatan dalam peningkatan kualitas pelayanan publik yaitu Putusan Mahkamah Agung Nomor 42 K/Kr/1965 tertanggal 8 Januari 1966, yang menetapkan: ${ }^{9}$ Suatu tindakan pada umumnya dapat hilang sifatnya sebagai melawan hukum bukan hanya berdasarkan suatu ketentuan dalam perundang-undangan, melainkan juga berdasarkan azas-azas hukum yang tidak tertulis dan bersifat umum, dalam perkara ini misalnya factor-faktor negara tidak dirugikan, kepentingan umum dilayani, dan terdakwa sendiri tidak mendapat untung. Sama halnya dengan bidang pemerintahan, maka dapatlah dikatakan bahwa dengan keputusan itu telah terpenuhi "azas-azas umum pemerintahan yang baik" atau dapat juga disebut sebagai telah memenuhi azas-azas umum peradilan yang baik."
Retno Mawarini .S, Membangun Legal Basis Pengisian Jabatan

Selanjutnya ada putusan hakim MA yang salah satu pertimbangannya adalah demi kepentingan umum dalam rangka memberikan kualitas pelayanan umum $^{10}$ yaitu Putusan Mahkamah Agung RI No.12 $\mathrm{P} / \mathrm{HUM} / 2003$. secara primer hakim menolak permohonan HUM tetapi secara subsider mengabulkan permohonan HUM untuk sebagiankan dalam pokok perkara bahwa pengelolaan kepelabuhan menurut Peraturan yang dikeluarkan Pemerintah hanyalah untuk kepentingan dan kesejahteraan pemerintah pusat saja yang seharusnya lebih mementingkan local society (masyarakat daerah) sesuai dengan kewenangan yang diberikan kepada daerah dengan semangat otonomi daerah, pertimbangan hakim menganut prinsip salus popilis supremalex yang mengandung makna bahwa kehendak rakyat adalah kehendak hukum tertinggi.

Dari contoh putusan diatas menunjukkan bahwa penerapan pertimbangan hakim berdasar pada kepentingan umum. Maka sebenarnya azasazas umum pemerintahan yang baik di Indonesia perkembangannya, telah menunjukkan keberpihakan terhadap kepentingan umum yang didalamnya melekat pelayanan publik dan sangat signifikan dengan perkembangan penyelenggaraan pemerintahan. Diharapkan saat mendatang, jika telah mendapat pemantapan melalui pengakuan jurisprudensi sebagai sumber hukum positif di Indonesia, hal ini akan mempunyai peran yang besar guna mengurangi ketakutan administrasi Negara untuk melakukan tindakan, atau paling tidak merupakan jalan keluar terhadap resiko stagnannya pelayanan umum. Legal Basis ditingkat daerah dalam pengisian jabatan sangat ditunggu kehadirannya, bukan untuk membatasi kewenangan tetapi justru diharapkan nantinya dapat memberikan kontribusi positif terhadap peningkatan kualitas pelayanan publik. Tentunya dibarengi materi muatan Perda yang dapat mendorong terwujudnya kompetensi jabatan struktural yang dibutuhkan.

\footnotetext{
${ }^{8}$ Notohamidjojo, 1970, Demokrasi Pancasila, Jakarta, BPK, hlm38.

${ }^{9}$ Jazim Hamidi, 1999, Azas-Azas Umum Penyelenggaraan Pemerintahan Yang Layak (AAUPPL) Di Lingkungan Peradilan Administrasi Indonesia, Bandung, Citra Aditya Bhakti, hlm. 65 .

${ }^{10}$ Dalam disertasi,Retno Mawarini S, putusan hakim MA yang salah satu pertimbangannya adalah demi kepentingan umum dalam rangka memberikan kualitas pelayanan umum salah satu putusan hakim MA: Putusan Mahkamah Agung RI No.12 P/HUM/2003 dengan semangat otonomi daerah dan kewenangan yang diberikan daerah maka salah satu pertimbangannya lebih mengedepankan kehendak rakyat adalah hukum tertinggi artinya lebih mengutamakan kepentingan umum yang di dalamnya melekat pelayanan publik , FH Universitas Gadjah Mada Yogyakarta, hlm. 212.
} 
Masalah - Masalah Hukum, Jilid 44 No.3, Juli 2015

Undang-Undang Nomor 28 Tahun 1999 tentang Penyelenggara Negara yang Bersih dan Bebas dari KKN, yang diharapkan dapat meningkatkan kualitas birokrasi, ternyata tidak bisa berbuat banyak contoh promosi jabatan acapkali tidak melihat penilaian prestasi dan kepangkatan, hampir terjadi disemua daerah, terutama setelah adanya pengelolaan kepegawaian secara mandiri. Untuk itu reformasi birokrasi, khususnya dalam rekrutmen jabatan struktural merupakan suatu kebutuhan yang tidak dapat ditunda lagi, terutama dalam rangka peningkatan pelayanan publik, dan merupakan tindakan pencegahan terjadinya korupsi. paradigma birokrasi sebagai pamong masih dirasakan, pelayanan masyarakat dijalankan setelah dirinya mendapat pelayanan terlebih dahulu.Paradigma inilah yang perlu dihilangkan guna mewujudkan peningkatan pelayanan publik.

\section{Simpulan}

Berdasarkan hasil penelitian dan pembahasan dapat ditarik kesimpulan, sebagai berikut:

1. Merupakan kebutuhan yang sangat mendesak, dan tidak perlu lagi menunda-nunda untuk melakukan reformasi birokrasi dalam penataan regulasi kepegawaian daerah khususnya pengisian jabatan yang berdasar pada profesionalisme dalam rangka peningkatan pelayanan publik dengan bersandar pada akuntabilitas, transparan, responsibilitas dan orientasi pelayanan dalam bentuk Perda sebagai peraturan pelaksanaan di daerah.

2. Penghapusan politisasi birokrasi.

3. Peningkatan peran dan eksistensi lembaga pengawasan birokrasi yang independent.

4. Pentingnya materi muatan Peraturan Daerah terhadap komitmen dalam menjalankan tugas jabatan, serta obyektifitas penilaian kinerja bagi pejabat structural.

\section{DAFTAR PUSTAKA}

\section{Buku}

Budiardjo, Miriam 1980, Masalah Kenegaraan, Jakarta, Gramedia.

Dunn, N. William, Muhadjir Darwin (Penyunting), 2001, Analisis Kebijaksanaan Publik: Kerangka Analisis Dan Prosedur Perumusan Masalah, Yogyakarta, Hanindita.

Hadjon, Philipus M, 1987, Perlindungan Hukum Bagi Rakyat di Indonesia, Surabaya, Bina Ilmu.

Hamidi, Jazim, 1999, Asas-asas Umum Penyelenggaraan Pemerintahan Yang Layak (AAUPPL) di Lingkungan Peradilan Administrasi Indonesia, Bandung, Citra Aditya Bhakti.

Kelsen, Hans, 1978, Pure Theory of Law, Berkeley, London,University of California Press.

Manan, Bagir, 1995. Hubungan antara Pemerintah Pusat dan Daerah Menurut UUD 1945, Jakarta, Sinar Harapan.

Muchsan, 2000, Sistem Pengawasan Terhadap

Perbuatan Aparat Pemerintah Dan

Peradilan Tata Usaha Negara Di Indonesia, Yogyakarta, Liberty.

Notohamidjojo, 1970, Demokrasi Pancasila, Jakarta, BPK.

Thalib, Dahlan 2004, Teori dan Hukum Konstitusi, Jakarta, Rajawali Press.

Wahyono, Padmo 1982, Negara Republik Indonesia, Jakarta, Rajawali.

\section{Jurnal dan Makalah}

Sukmariningsih, Retno Mawarini, 2014, "The right Man On The Right Job : Does the Local Regulation Support It ? The Empirical Evidence From Central Java,Indonesia," Hyderabad,India, International Journal of Managerial Studies and Research Volume 2 ,Issue 3, Academicians Research Center. 
Taufik effendi, 2008."Permasalahan dan Peningkatan Kinerja SDM Aparatur Negara Menghadapi Persaingan Global", Dipresentasikan di UNDIP, Semarang.

Peraturan Perundang-Undangan:

Undang-Undang Nomor 28 Tahun 1999 tentang Penyelenggaraan Negara yang bersih dan bebas dari Korupsi, Kolusi dan Nepotisme;

Undang-Undang Nomor 25 Tahun 2009 tentang Pelayanan Publik;

Undang-Undang Nomor 5 Tahun 2014 tentang Aparatur Sipil Negara; 